\title{
23. Establishing the Selection Method for the Lentinula edodes Strains Resistant to Trichoderma spp.*)
}

\author{
By Keisuke Tokimoto, Mitsuo Komatsu, and Yukitaka FukUmasa-NAKAI \\ The Tottori Mycological Institute, 211 Kokoge, Tottori 689-11
}

(Communicated by Naohide Hiratsuka, M. J. A., Sept. 12, 1994)

\begin{abstract}
Trichoderma inoculation tests for cultures of 89 different shiitake (Lentinula edodes) strains showed that the resistance of shiitake in a wood-powder medium correlated positively to that in 28-month-old bedlogs when $T$. harzianum was inoculated. Mycelial growth rate of shiitake in an agar medium or in the wood-powder medium also was correlated with the resistance of shiitake bedlogs, although the interaction in the agar medium appeared to be irrelevant. The amount of damage to shiitake caused by $T$. harzianum had a positive correlation with that by $T$. polysporum both in the wood-powder medium and in bedlogs. Strains having a high wood-rotting ability in bedlogs tended to have the ability to reject Trichoderma in the wood-powder medium. The inhibition rates of shiitake mycelial growth by trichopolyn proved not to correlate to the rate of damage by $T$. polysporum.
\end{abstract}

Key words: Shiitake cultivation; Lentinula edodes; selection method for resistant strain; damage by Trichoderma.

Introduction. In recent years, the cultivation of shiitake, Lentinula edodes (Berk.) Pegler [Lentinus edodes (Berk.) Singer], has spread to many countries throughout the world. However, Trichoderma spp., such as T. harzianum and T. polysporum, often attack and kill shiitake mycelium in bedlogs (Arita, 1971; Komatsu, 1976) by producing antifungal substances (Fuji et al., 1978) and mycolytic enzymes (Tokimoto, 1982; Kitamoto et al., 1984; Ulhoa and Perberdy, 1992) that reduce fruiting body yield. On the other hand, shiitake are more or less able to resist a Trichoderma attack. Shiitake cultures have produced at least five straight-chain alcohols, having double and triple bonds, which act as antifungal substances. These substances probably play a role in shiitake resistance against Trichoderma, because the kind and amount of them increased during a Trichoderma attack (Tokimoto et al., 1987). A useful selection method is required to breed resistant strains of shiitake but there has been insufficient information about how to carry this out (Tokimoto, 1984; Hasebe, 1991). In this study, we observed the resistance of shiitake strains against Trichoderma in various conditions to create a useful in vitro bioassay method for selecting resistant strains.

Materials and methods. Strains. Eighty-nine different wild (dikaryotic) strains of shiitake, collected from various parts of Japan, and two Trichoderma strains, $T$. harzianum Rifai (TMI-60622) and T. polysporum Rifai (TMI-60146) were used. These were obtained from the culture collections of the Tottori Mycological Institute.

Dual culture in an agar medium. Wood-powder of Quercus serrata was extracted with hot water $(10 \%$, w/v) for $30 \mathrm{~min}$. To the supernatant fluid of the extract, $0.1 \%$ casamino acids (Difco.), $1.0 \%$ glucose, and $1.5 \%$ agar was added. After autoclaving, a plate medium ( $20 \mathrm{ml} / 9 \mathrm{~cm}$-dish) was prepared. A $5 \mathrm{~mm}$ diam plug from an agar plate of shiitake was used to inoculate the center of the dish, then incubated at $25^{\circ} \mathrm{C}$. Extension rate of the

*) Contribution no. 291 from the Tottori Mycological Institute. 
mycelial colony (from day 3 to day 6) was determined. A $5 \mathrm{~mm}$ diam plug of Trichoderma mycelium on the agar medium was placed on the 12-day-old shiitake mycelial colony. After three days' incubation at $25^{\circ} \mathrm{C}$, the diameter of the invaded circle of the shiitake colony was measured.

Dual culture in a wood-powder medium. With 1,000 $\mathrm{g}$ of dried powder of Fagus crenata wood (passed through a 24-mesh screen), $1.5 \mathrm{~g}$ of ammonium sulfate, and $1,850 \mathrm{~g}$ of distilled water were mixed. This mixture was filled in glass tubes, $20 \mathrm{~mm}$ in diameter and $200 \mathrm{~mm}$ in length, leaving $20 \mathrm{~mm}$-wide spaces on both sides. The ends of the glass tubes were capped with air permeable silicon plugs (Shinetsu Chem. Co.). Moisture content of the medium on a fresh weight basis was $64 \%$ after autoclaving. A $5 \mathrm{~mm}$ diam disk of shiitake mycelium on agar medium was inoculated at one end of the tube and allowed to grow at $25^{\circ} \mathrm{C}$ in the dark. Mycelial elongation $(\mathrm{mm})$ from day 14 to day 30 was measured. Then, a piece of the medium at the inoculation side, $10 \mathrm{~mm}$ wide, was removed, and the 10 $\mathrm{mm}$ space was filled with the Trichoderma wood-powder culture. After 7 and 14 days' incubation at $25^{\circ} \mathrm{C}$, the degree of Trichoderma mycelial invasion into the shiitake mycelial colony was measured.

Preparation of bedlogs. Plug type of shiitake spawn (Fagus crenata wood: $8.5 \mathrm{~mm}$ diam, $12 \mathrm{~mm}$ length) of each strain was prepared and inoculated to Quercus serrara logs (8-12 cm diam, $100 \mathrm{~cm}$ length) using a common method (Japan Kinoko Res. Cent., 1986). These logs were placed under a tree in a forest to develop shiitake mycelium and to produce fruiting bodies for 28 months.

Inoculation of Trichoderma into shiitake bedlogs. After 28 months, bedlogs were submerged in water for $24 \mathrm{~h}$, then basic density (weight in oven dry/volume in fresh sample) and fresh basis water content in the sapwood were determined. Also, six column holes (12 mm diam, $20 \mathrm{~mm}$ depth) were made on each bedlog. Wood-powder Trichoderma cultures were inoculated into the holes (one $\mathrm{g}$ fresh wt/hole), then capped with polypropylene plugs. After seven days' incubation at $25^{\circ} \mathrm{C}$, the bark of the bedlogs was taken off and the damaged areas on the sapwood surface were measured.

Inhibition of mycelial growth by trichopolyn. T. polysporum was stationarily incubated in a semi-synthetic liquid medium containing casamino acids $2 \mathrm{~g}$, glucose $20 \mathrm{~g}$, $\mathrm{KH}_{2} \mathrm{PO}_{4} 1.0 \mathrm{~g}, \mathrm{MgSO}_{4} \cdot 7 \mathrm{H}_{2} \mathrm{O} 0.5 \mathrm{~g}, \mathrm{CaCl}_{2} \cdot 2 \mathrm{H}_{2} \mathrm{O} 0.1 \mathrm{~g}$, adenine hydrochloride $5.0 \mathrm{mg}$, thiamine hydrochloride $0.1 \mathrm{mg}$, and trace elements per liter of distilled water (Tokimoto, 1982). Trichopolyn, an antibiotic, was isolated from the filtrate by the method of Fuji et al. (1978). Agar media containing the same nutrients as the semi-synthetic liquid medium were prepared with or without trichopolyn $(5 \mathrm{ppm})$. Mycelial growth rates (colonial extension at $25^{\circ} \mathrm{C}$ ) on the two plate media were measured, and the inhibition rate [1 (with trichopolyn) / (without trichopolyn)] was determined.

Results and discussion. In this study, three to six replicates per treatment were made, and all the characters investigated showed significant differences $(0.1 \%$ level $)$ among strains of shiitake after variance analyses (data not shown).

The extent of damage of different shiitake strains in the agar, wood-powder media, and bedlogs varied widely among strains (Table I). In the wood-powder medium, the ranges and variances $(\mathrm{SD}$ and $\mathrm{CV}$ ) on the 14th day of interaction were larger than those on the 7th day, both in T. harzianum and in T. polysporum. On the 14th day, many shiitake strains conversely invaded the Trichoderma side, especially against $T$. harzianum. In 28-month-old bedlogs, the rate of damage caused by the two Trichoderma spp. after seven days' incubation showed higher variations among strains of shiitake, compared to those on the 7 th day in the wood-powder medium.

Trichopolyn inhibits mycelial growth of $L$. edodes (Fuji et al., 1978; Tokimoto, 1984). Five ppm of this antibiotic results in a higher than $70 \%$ rate of inhibition of mycelial growth 
Table I. Mean and variation of characters studied in 89 different shiitake strains used

\begin{tabular}{|c|c|c|c|c|c|c|}
\hline $\begin{array}{l}\text { Substrate of } \\
\text { culture }\end{array}$ & Character & Mean & $\mathrm{SD}^{1)}$ & $\mathrm{CV}^{2)}$ & $\operatorname{Min}^{3)}$ & $\operatorname{Max}^{4)}$ \\
\hline \multirow[t]{5}{*}{$\begin{array}{l}\text { Wood-powder } \\
\text { medium }\end{array}$} & $\begin{array}{l}\text { Mycelial } \\
\text { growth (mm/14 days) }\end{array}$ & 60.8 & 6.0 & 9.87 & 40 & 74 \\
\hline & $\begin{array}{l}\text { Damage by } T \text {. harzianum } \\
\text { on day } 7(\mathrm{~mm})\end{array}$ & 14.1 & 7.4 & 52.5 & 0 & 37 \\
\hline & $\begin{array}{l}\text { Damage by } T . \text { harzianum } \\
\text { on day } 14(\mathrm{~mm})\end{array}$ & 7.0 & 12.6 & 180 & -15 & 59 \\
\hline & $\begin{array}{l}\text { Damage by } T \text {. polysporum } \\
\text { on day } 7(\mathrm{~mm})\end{array}$ & 18.2 & 7.9 & 43.4 & 0 & 34 \\
\hline & $\begin{array}{l}\text { Damage by } T \text {. polysporum } \\
\text { on day } 14(\mathrm{~mm})\end{array}$ & 14.9 & 14.1 & 94.6 & -13 & 41 \\
\hline \multirow[t]{3}{*}{ Agar medium } & $\begin{array}{l}\text { Mycelial growth } \\
(\mathrm{mm} / 3 \text { days })\end{array}$ & 15.3 & 3.6 & 23.5 & 49 & 223 \\
\hline & $\begin{array}{l}\text { Damage by } T \text {. harzianum } \\
\text { on day } 3(\mathrm{~mm})\end{array}$ & 15.6 & 11.4 & 73.1 & 7 & 39 \\
\hline & $\begin{array}{l}\text { Inhibit }(\%) \text { of mycelial } \\
\text { growth by trichopolyn }\end{array}$ & 92.8 & 8.6 & 9.27 & 64 & 100 \\
\hline \multirow[t]{4}{*}{$\begin{array}{l}\text { 28-month- } \\
\text { old bedlogs }\end{array}$} & $\begin{array}{l}\text { Wet basis water } \\
\text { content }(\%)\end{array}$ & 53.6 & 7.6 & 14.2 & 35.4 & 72.6 \\
\hline & $\begin{array}{l}\text { Basic density } \\
\left(\mathrm{g} / \mathrm{cm}^{3}\right)\end{array}$ & 0.382 & 0.054 & 14.1 & 0.216 & 0.492 \\
\hline & $\begin{array}{l}\text { Damage by } \\
T . \text { harzianum }\left(\mathrm{mm}^{2}\right)\end{array}$ & 276 & 351 & 127 & 15 & 2550 \\
\hline & $\begin{array}{l}\text { Damage by } \\
T . \text { polysporum }\left(\mathrm{mm}^{2}\right)\end{array}$ & 323 & 264 & 81.7 & 51 & 1940 \\
\hline
\end{tabular}

${ }^{1)}$ Standard deviation, ${ }^{2)}$ Coefficient of variation, ${ }^{3)}$ Minimum value, ${ }^{4)}$ Maximum value.

in most strains, although 3 of 89 strains exhibited less than $70 \%$ inhibition (Table I).

Table II shows the correlation coefficients of the various characters investigated. The rate of damage of shiitake strains by $T$. harzianum positively correlated with those by $T$. polysporum, both in the wood-powder medium and in bedlogs. This indicates that resistance of shiitake strain tends to be common to species of Trichoderma. When $T$. harzianum was inoculated, the rate of damage of shiitake in the wood-powder medium showed positive correlation to that in the 28-month-old bedlogs, although no correlation was observed in the case of $T$. polysporum. This inconsistency between the two Trichoderma species remained unsolved.

Basic density in the 28-month-old bedlogs positively correlated to the damage in the wood-powder medium. This indicates that strains having a high wood-rotting ability show a good ability to reject Trichoderma in less rotted substrates. In the bedlogs, water content showed no significant correlation to the damage rate by Trichoderma, although Trichoderma grew at lower water potentials than did shiitake (Badham, 1991).

The inhibition rate of mycelial growth by trichopolyn showed a high correlation to the rates of mycelial growth in the agar medium. Therefore, faster growing strains are more 
Table II. Correlation coefficients among characters studied ${ }^{1)}$

\begin{tabular}{|c|c|c|c|c|c|c|c|c|c|c|c|c|}
\hline & & Bed & $\log$ & & & Wood-p & powder m & dium & & & gar medium & \\
\hline & Moisture & Basic & Dama & age by & Mycelial & & Dama & e by & & Mycelial & Damage by & Inhibit \\
\hline & content & density & T. harzi- & T. polys- & growth & T. harz & zianum & T. polys & porum & growth & T. harzia- & by $\mathrm{TP}$ \\
\hline & (1) & (2) & (3) & (4) & (5) & $\begin{array}{c}\text { day } 7 \\
(6)\end{array}$ & $\begin{array}{l}\text { day } 14 \\
(7)\end{array}$ & $\begin{array}{c}\text { day } 7 \\
(8)\end{array}$ & $\begin{array}{c}\text { day } 14 \\
(9)\end{array}$ & (10) & (11) & (12) \\
\hline (2) & $-0.449^{* *)}$ & & & & & & & & & & & \\
\hline (3) & 0.089 & 0.041 & & & & & & & & & & \\
\hline (4) & -0.173 & 0.137 & $0.229 *)$ & & & & & & & & & \\
\hline (5) & -0.167 & $0.201^{*)}$ & 0.046 & $0.193^{*)}$ & & & & & & & & \\
\hline (6) & $\left.-0.200^{*}\right)$ & $0.232 *)$ & $0.219^{*)}$ & 0.081 & -0.099 & & & & & & & \\
\hline (7) & 0.006 & 0.079 & $0.287^{* *)}$ & 0.059 & $-0.184^{*)}$ & $0.523^{* *)}$ & & & & & & \\
\hline (8) & -0.062 & $0.309^{* *)}$ & 0.018 & 0.013 & -0.008 & $0.219^{*)}$ & 0.166 & & & & & \\
\hline (9) & 0.022 & $0.242^{*)}$ & -0.007 & -0.014 & -0.066 & $0.250^{* *)}$ & $0.226^{*)}$ & $0.905^{* *)}$ & & & & \\
\hline (10) & -0.064 & -0.016 & $-0.200^{*)}$ & 0.020 & $0.249^{* *)}$ & 0.030 & -0.019 & 0.022 & 0.031 & & & \\
\hline (11) & -0.009 & 0.095 & 0.008 & -0.145 & 0.022 & -0.016 & -0.033 & 0.185 & 0.174 & -0.131 & & \\
\hline (12) & 0.123 & 0.004 & 0.090 & -0.175 & -0.090 & -0.024 & $\left.0.200^{*}\right)$ & -0.044 & 0.017 & $0.287^{* *)}$ & 0.122 & \\
\hline
\end{tabular}

1) Calculated from the data of 89 different shiitake strains.

*), **): Significant at $5 \%$ and $1 \%$, respectively.

Table III. Regression formulae between the damage rate of bedlogs by Trichoderma and some characters studied

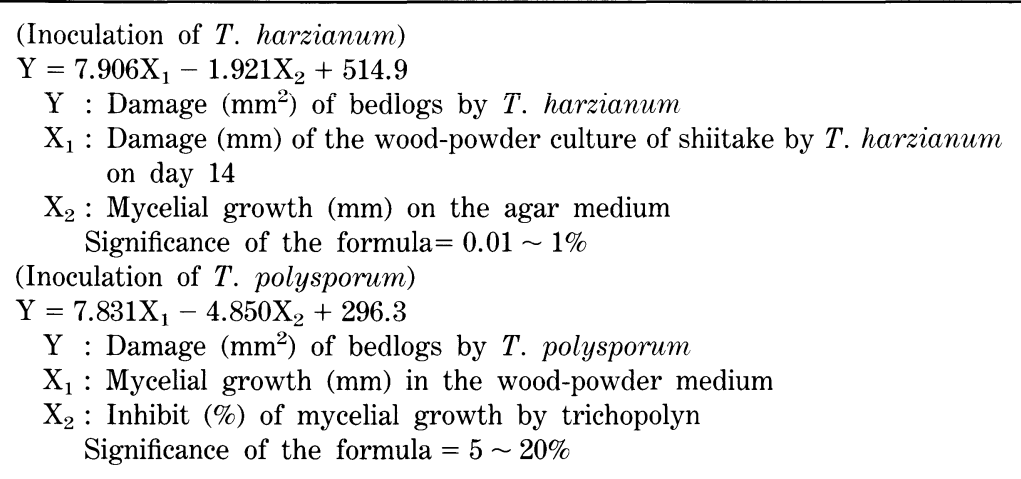

inhibited by trichopolyn. The medium containing trichopolyn cannot be used to select strains resistant against $T$. polysporum because there was no clear correlation between the trichopolyn inhibition rate and the rate of damage by $T$. polysporum.

Multiple regression analyses (Table III) showed that the damage rate of bedlogs by $T$. harzianum was predicted by the damaged rate in the wood-powder medium and by the mycelial growth rate in the agar medium. However, we could not obtain a significant formula when $T$. polysporum was inoculated. One of the important problems to be solved is to create a useful in vitro method for selecting resistant strains of shiitake, which is adapted for not only T. harzianum but also T. polysporum.

Acknowledgments. We express our gratitude to Dr. N. Hiratsuka, M. J. A., Director of the Tottori Mycological Institute, and Dr. R. W. Kerrigan, Research Director of Sylvan 
Spawn Laboratory, for suggestions and critical reading of the manuscript. This work was supported in part by a grant from the Forest Agency of Japan.

\section{References}

Arita, I. (1971): Rept. Tottori Mycol. Inst., 9, 36-56 (in Japanese with English abstract). Badham, E. (1991): Mycologia, 83, 455-463.

Fuji, E. et al. (1978): Experientia, 34, 237-238.

Hasebe, K. (1991): Rept. Tottori Mycol. Inst., 29, 1-69 (in Japanese with English abstract). Japan Kinoko Res. Cent. (1986): Shiitake Saibai no Gijutsu to Keiei, Ieno-Hikari Kyokai, p. 221 (in Japanese).

Kitamoto, Y. et al. (1984): Trans. Mycol. Soc. Japan, 26, 69-79.

Komatsu, M. (1976): Rept. Tottori Mycol. Inst., 13, 1-113 (in Japanese with English abstract).

Tokimoto, K. (1982): Trans. Mycol. Soc. Japan, 23, 13-20.

- (1984): Rept. Tottori Mycol. Inst., 23, 1-54 (in Japanese with English abstract).

Tokimoto, K. et al. (1987): Proc. Japan Acad., 63B, 277-280.

Ulhoa, C. J., and Perberdy, J. F. (1992): Enzyme Microb. Technol., 14, 236-240. 